\title{
OPEN BORDERS AND BRAIN DRAIN: A MORAL DIMENSION
}

\author{
Emmanuel Ifeanyi Ani \\ University of Ghana, Accra, Ghana
}

\begin{abstract}
The moral debate about open borders needs to go beyond focusing on the interests of the migrant versus the interests of the hosting state and its original citizens to focusing more on the interests of the countries that migrants are leaving. I hint at the long-term insufficiency of so-called economic remittances to the development of migrant-sending states when compared to domiciled skilled labor. But most importantly, I identify the irrelevance of current empirical research on brain drain to an open borders scenario. I hint at the potential scale of brain drain in such a scenario, and I raise a moral question about the propriety of proposing open borders with a focus on the wellbeing of the individual migrant if such a focus is determined to be at the expense of the wellbeing of the migrant's home country. I add that a preamble to opening borders would be to significantly address gross global economic disparities, world poverty, and political injustices.
\end{abstract}

\section{INTRODUCTION}

Whilst open border theorists hammer on the moral worth of all humans, equality of opportunity, and the universal right to free movement, closed border theorists insist on the right of host communities to self-determination, including the right to determine who not to associate themselves with, and other arguments about national interests, cultural stability and the preservation of the patriotism of original citizens. The debate is quite stuck in this way, and we need to move it to refreshing platforms. One such platform is the imagined effect of open borders on the economic fate (and ultimately the self-determination) of countries losing migrants. All previous empirical research on brain drain is based on closed borders, and I raise the possibility that open borders present not just an unprecedented economic challenge but also a threat to the democratic viability of countries losing mass migrants. Anticipating that opening borders is not to the advantage of sending countries, I raise the moral question about proposing open borders if it hurts the migrant's country whilst temporarily providing relief to the migrant. To do all this, I begin the first section by reviewing the classical open border debate and considering its somewhat grid-locked nature; I go further to review new platforms in the debate (which I call the context-driven debate). Then I 
present another context-based approach by discussing open borders in the context of brain drain, a scenario that no empirical scholar has yet tried to imagine or conjecture. I raise moral questions that this scenario brings to the open border debate. I argue that the debate will be more robust by taking this context seriously and that more research is needed on what open borders could actually do to migrant-sending countries.

\section{THE CLASSICAL OPEN BORDER DEBATE}

In referring to the 'Classical' open border debate, I am borrowing a term used by Amy Reed-Sandoval (2016), who uses the term to describe the way early proponents and opponents of open borders defended their positions: by appealing to universal democratic principles. Whilst early proponents of open borders argued that the universal right to freedom of movement supports open borders, early opponents of open borders argued that the right to self-determination as well as the right to freedom of association (including the right not to associate) supports the decision of states to exclude immigrants. The early proponents of open border (whom I call the cosmopolitans) combined the right to freedom of movement with the notion that the human being is, first and foremost, a citizen of the entire world. I will refer to some examples. Phillip Cole $(2011,4)$ argues that the debate is about "ethics" of migration, not politics. He reminds us that the moral equality of humanity is an ideal of liberal theory. He then charges that states have substituted this for the moral equality of members of a particular political community. In his view, either we embrace ethical universalism, or we provide a coherent defense of partialism. Cole $(2011,5)$ adds that it is contradictory for liberal states to protect the right of their citizens to emigrate and restrict the right of foreigners to immigrate.

Joseph Carens began his campaign for open borders when he became interested in reports of Haitians who were trying to reach Florida to ask for asylum as refugees (Carens 2013, ix). The way he begins his book shows that Carens is focused on the welfare of the individual migrant. He (2013, ix) writes that he felt "intuitively torn between the feeling that there was something wrong in excluding people in such obvious need and the worry that admitting everyone with comparable claims would be overwhelming and would be especially harmful to those already most disadvantaged in America." He then outlines two basic issues in the immigration debate going on all over Europe and North America: first, "what states should do to regulate entry," and second, "how those who have arrived should be treated" (Carens 2013, 2). In the first part of his book, Carens discusses the second issue in several chapters (such as citizenship, naturalization, temporary work, refugees, and others), and in the second part, he steps back from the political tensions and practical policy concerns attending to these debates in order to examine the issue at a moral level, since he thinks that they raise ethical questions and that our commitment to democratic principles greatly constrain the way we can answer those questions. By "democratic principle," Carens refers to "the broad moral commitments that underlie and justify contemporary political institutions and policies throughout North America and Europe," such as the 
ideas that all humans are of equal worth, that we have a duty to respect the rights and freedoms of others, that all citizens are equal under the law, that the legitimacy of a government depends on the consent of the governed, and other democratic principles that we are familiar with (See Carens 2013, 2).

Carens adds that these principles have also been termed "liberal," "liberal democratic," or "republican." He argues that liberals, democrats, and republicans share a broad consensus on these principles, and Carens takes the democratic normative framework emerging from this consensus as a launching pad for examining the ethical issues arising from immigration. He begins by taking a shot at the idea that state sovereignty and the democratic self-determination of the people of a state both preclude a moral questioning of immigration. He agrees that states and citizens of states are free to make their decisions about admitting migrants. However, he argues that this freedom does not prevent a moral inquiry into their decisions. Regarding the idea that immigration decisions are not moral because they are taken by sovereign states and self-determining peoples, Carens $(2013,6)$ writes, "It confuses the question of who ought to have the authority to determine a policy with the question of whether a given policy is morally acceptable." Carens thinks we should separate both issues: who decides and the morality of the decision. He cites the terrible immigration decisions taken by many European countries (included the notorious US Chinese Exclusion Act prohibiting Chinese from immigrating to the US and the dreaded Nuremberg Laws stripping German Jews of their citizenship). He asks whether these are immune from moral inquiry simply because they were decisions taken by sovereign states and self-determining peoples.

Carens then argues that borders should open and defends his proposition by appealing to three assumptions that are accepted by all states, including the states restricting large numbers of immigrants. The first assumption is that "there is no natural order. The institutions and practices that govern human beings are ones that human beings have created and can change, at least in principle" (Carens 2013, 226). The second assumption is that "all human beings are of equal moral worth" (Carens 2013, 226). And the third assumption is that restrictions on freedom of human movement "require a moral justification" (Carens 2013, 226). Carens reminds us that contemporary democratic governments pay some respect to these three assumptions, and on their bases, Carens argues for open borders for three reasons. The first reason, according to him, is that state control limits the freedom of movement. He $(2013,227)$ writes,

The right to go where you want is an important human freedom in itself. It is precisely this freedom, and all that this freedom makes possible, that is taken away by imprisonment. Freedom of movement is also a prerequisite to many other freedoms. If people are to be free to live their lives as they choose, so long as this does not interfere with the legitimate claims of others, they have to be free to move where they want. This freedom of movement contributes to individual autonomy both directly and indirectly. Open borders would enhance this freedom. 
Carens does not deny that freedom of movement needs to be constrained; what he says is that such constraints need moral justification, in the form of "some argument as to why the restriction on freedom is in the interest of, and fair to, all those who are subject to it" (Carens 2013, 227). He, therefore, argues that states need moral justification for their restrictions on movement since they are restricting freedom of movement. Carens $(2013,227)$ argues that the justification must consider "the interests of those excluded as well as the interests of those already inside." Then Carens makes a point that I intend to use against his position. This point is his statement that states must make a case that restrictions on immigration "are fair to all human beings" (Carens 2013, 227). Carens adds that although there are certain restrictions that meet this standard of justification, "granting states a right to exercise discretionary control over immigration does not" (Carens 2013, 227).

The second reason that Carens gives for his open border proposal is that we need freedom of movement to achieve the ideal of equality of opportunity. In his (2013, 227-228) words,

\begin{abstract}
Within democratic states, we all recognize, at least in principle, that access to social positions should be determined by an individual's actual talents and effort and not limited on the basis of birth-related characteristics such as class, race, or gender that are not relevant to the capacity to perform well in the position. This ideal of equal opportunity is intimately linked with the idea that all human beings are of equal moral worth, that there are no natural hierarchies of birth that entitle people to advantageous social positions. But you have to be able to move to where the opportunities are in order to take advantage of them. So, freedom of movement is an essential prerequisite for equality of opportunity.
\end{abstract}

On the basis of freedom of movement and its importance to the equality of opportunity, Carens compares current immigration restrictions to what happened under feudalism. He argues that citizenship in Western democracies is equivalent to feudal class privilege; being born into Western democracy and into a feudal nobility look alike. And being born into Asia or Africa is equivalent to being born into "the peasantry of the middle ages (even if there are a few rich peasants and some peasants manage to gain entry into the nobility)" (Carens 2013, 226). It means that modern social arrangements, just like a feudal birthright, grant privileges on the basis of birth, and "entrench these advantages by legally restricting mobility, making it extremely difficult for those born into a socially disadvantaged position to overcome that disadvantage, no matter how talented they are or how hard they work" (Carens 2013, 226). If, Carens asks, feudal practices protecting birthright privileges were wrong, "what justifies the modern ones?" (Carens 2013, 226).

Carens admits that in the modern world, we feel committed to equality of opportunity within democratic states, but with our current immigration prototype, we make no pretense or even aspire to this ideal across states. And because opportunities 
are greatly unequal across states, it means we are no different from feudal states in allowing the social circumstances of one's birth to determine her opportunities (Carens 2013, 228). Carens concludes his argument by reminding us that commitment to equal moral worth entails a commitment to social, economic, and political equality. He (2013, 228) writes, "Freedom of movement would contribute to a reduction of political, social and economic inequalities. There are millions of people in poor states today who long for the freedom and economic opportunity they could find in Europe and North America. Many of them take great risks to come. If the borders are opened, millions more would come."

Carens $(2013,231)$ clarifies that by open borders, he does not mean the absence of borders. By open borders, he means that with some restrictions, "borders should be open to just about anyone who wishes to migrate internationally" (Reed-Sandoval $2016,18)$. In principle, "borders should generally be open, and people should normally be free to leave their country of origin and settle in another" (Carens 2013, 225).

Opponents of open borders have reacted to the challenge of Cole and Clarens by zeroing in on the right to self-determination, among other values that support community bonding. Christopher Heath Wellman believes that states should have the moral right to exclude. In his words, "legitimate political states are morally entitled to unilaterally design and enforce their own immigration policies, even if these policies exclude potential immigrants who desperately want to enter" (Wellman and Cole 2011, 13). Wellman advances three premises for his claim. They are "(1) legitimate states are entitled to political self-determination, (2) freedom of association is an integral component of self-determination, and (3) freedom of association entitles one to not associate with others" (Wellman and Cole 2011, 13). Defending premise (1) on self-determination, Wellman cites the example of the Nuremberg trials, which were set up by the Allies to prosecute Nazi officials for their atrocities against Jews and others. Wellman cites the objection at that time that this breached the principle of German self-determination. He (Wellman and Cole 2011, 13-14) writes,

... critics objected that the Allied Powers had no business prosecuting and punishing Germans for crimes they had committed against their fellow citizens and subjects. In particular, while far fewer would have objected to punishing Nazi political and military leaders for waging an aggressive war, many thought it was inappropriate that outsiders should take it upon themselves to prosecute Germans for crimes against their compatriots.

Wellman clarifies that the objection was about jurisdiction rather than morality. He (Wellman and Cole 2011, 14) writes,

It is not that critics denied that these crimes were utterly horrific; rather, the worry was one of jurisdiction. No matter how badly one German mistreats another on German soil, this seems paradigmatically a matter for the German legal system; it is simply not the business of outsiders, and the Allied Powers were not morally entitled to make it their business merely because they had won the war. 
Wellman is not totally in agreement with this criticism, but he cites it as striking a chord with his argument on self-determination. He (Wellman and Cole 2011, 13) writes,

Although I am not ultimately convinced by this particular objection to the Nuremberg trials, I am sympathetic to its general motivation. In essence, this objection centers around Germany's right to self-determination. The prosecution of crimes by and against German subjects on German soil is thought to be a private matter for Germany as a whole to adjudicate because sovereign states are assumed to be morally entitled to design and operate their own systems of criminal law.

What Wellman finds to be of some merit in the principle of self-determination is that "while it may be permissible to punish Germans for their bellicosity toward other countries, it is wrong to prosecute Nazi leaders for their mistreatment of fellow Germans" (Wellman and Cole 2011, 15).

Let me cite a different sort of defense for the self-determination component of the statist perspective. This sort of defense comes from Michael Walzer, who argues that states should maintain closed borders in order to preserve cultural distinctiveness, arguing that distinctiveness needs some closure to be stable $(1983,39)$. He $(1983,62)$ writes,

Admissions and exclusion are at the core of communal independence. They suggest the deepest meaning of self-determination. Without them, there could not be communities of character, historically stable, ongoing associations of men and women with some special commitment to one another and some special sense of their common life.

Walzer's argument is that membership is itself a social good that is distributed by those who are already members in just the same way they distribute power to one another and avoid, if they possibly can, sharing it with someone else. He thinks that members of a community determine the distribution of goods in that community, and membership is one such good. Walzer $(1983,38)$ also argues that states should maintain closed borders in order for communities within the states to be open and inclusive to one another and that undermining the former is to undermine the latter.

Peter Higgins (2013) has described Walzer's argument (and similar ones) as 'prescriptive nationalist,' by which he means arguments about the state's right to decide on immigration based on "national interest." Let me cite two other similar "national interest" arguments. Stephen Marcedo (2007) argues that poor and lowskilled migrants have the effect of driving down the wages of the low-class citizens of migrant-receiving countries and that since they give employers the opportunity to hire progressively cheaper labor, they benefit the business class but make things worse for the working class. David Miller $(1995,23)$ argues that states have the right to close borders in order to preserve their national identity and that too much immigration could 
dilute this feeling to the extent that citizens become discouraged from sacrificing for the common good.

\section{THE CONTEXT-DRIVEN OPEN BORDER DEBATE}

Reed-Sandavoal $(2016,27)$ has argued that the nature of the Classical debate on open borders makes it an impasse and suggests that the debate is more constructive when argued in specific contexts, such as the contexts of post-colonialism, non-ideal theory, racism, and feminism. And she offers examples of this alternative methodology for arguing about the central question of the openness of borders. Let me briefly highlight some of these examples. Taking a post-colonial perspective, Phillip Cole (2000, 16-42) had argued that people do not just migrate to earn more money but to abandon the consequences of colonialism and military occupation and that they more often migrate to the countries that colonized their lands. Cole observes that the majority of US immigrants are from previously invaded countries such as Mexico, Vietnam, the Philippines, Korea, and the Dominican Republic (Reed-Sandoval 2016, 21). Shelley Wilcox provides a good example of a non-ideal theoretical perspective. She (2007, 27; cited in Reed-Sandoval 2016, 21-22) argues that the open border debate "fails to provide adequate guidance in the world as it is today." Wilcox $(2007,27$; cited in Reed-Sandoval 2016, 21-22) observes that even Clarens acknowledges that some justification could warrant state exclusion of a migrant, and this means that the open borders debate "cannot establish admissions priorities because it construes the right to immigrate strictly as a universal human right." Wilcox suggests that there are other moral grounds that are quite strong, apart from the universal right to freedom of movement. She advocates what she calls a "Global Harm Principle," by which liberal states should give admission priority to citizens of those states that they (liberal states) have harmed, for example, the victims of the US Military herbicide operations in the Vietnam war, who find it unhealthy to live in their homes, and who have not been spared from additional deficits including human rights deficits (Wilcox 2007, 285-286).

Carens also articulates arguments that presuppose a real world situation of closed borders, quite apart from his argument about open borders. In the first part of his book, The Ethics of Immigration, he proposes real world policies presupposing closed borders regarding the issues of birthright citizenship, naturalization, permanent residents, temporary workers, irregular workers, and refugees. Carens directs these arguments specifically to affluent European and North American countries, whom he knows are besieged with more immigrants. Although these arguments are made in the context of closed borders, they are still somewhat relevant to his open borders arguments.

There have also been feminist approaches to the open border debate. ReedSandoval mentions the works of Uma Narayan (1995), Shelley Wilcox (2005), ís:Alison Jaggar (2009), Serena Parekh (2012), Natalie Cisneros (2013), and Peter Higgins (2013). Reed-Sandoval particularly reports Eva Feder Kittay's description of "how female migrants leave comparatively poor nations to practice commodified caring labour in wealthy Western nations," a phenomenon Kittay terms 
the "global movement of caring labour" (Kittay 2009, 54; cited in Reed-Sandoval 2016, 24). This phenomenon causes what Kittay calls a "Global Heart Transplant" in which "many migrant women devote much of their direct caring efforts to children, elderly people, and the infirm in the wealthy Western countries to which they have migrated while their own children and families are left behind (generally out of economic necessity) to be cared for by another" (Kittay 2009, 54; cited in ReedSandoval 2016, 24). Kittay argues (Kittay 2009, 54; cited in Reed-Sandoval 2016, 24) that this Transplant harms women in spite of the economic benefits of migration since it deprives them of "the ability to care for the particular people in their lives towards whom they most wish to give care" (Emphasis in the original). Kittay $(2009,70)$, therefore, argues for the right of these migrant women to care for whom they want, and we could help this right by improving the working conditions of these women, including making it possible for these women to return home for lengthy vacations to visit their children and families, and reunification programmes enabling their families to join them in their countries of migration.

Taking a racial perspective, Sarah Fine (2016) argues that modern-day immigration controls developed as a result of, and in response to, institutionalized racism. They also continue to "promote and permit racist ends" (Fine 2016, 133). She $(2016,126)$, therefore, argues that not only should we remove racial criteria in immigration exclusions, but we should also "consider the requirements of rectificatory justice in conjunction with the ethics of immigration controls."

There are yet other contextual debates regarding open borders, such as those that focus on the lived experiences of Latin Americans and Latinas/Latinos in the United States. Some of these, as identified by Reed-Sandoval, include Linda Martin Alcoff (2006), Grant Silva (2015), Jose Jorge Mendoza (2015), Carlos Alberto Sanchez (2011), and Amy Reed- Sandoval (2015). To this body of literature, I propose to add yet another contextual approach to debating open borders: one that asks about the moral propriety of opening borders if it drains the skills in poorer economies, and ultimately, the self-determination of those countries.

\section{OPEN BORDERS AND BRAIN DRAIN}

In this article, I advance an ethical objection to open borders on the basis of its potentially disastrous effects on the manpower and democratic repositories of weaker economies. Unlike the supranational posturing of the Classical Open Border Cosmopolitans, I assume that we still live in sovereign states until otherwise determined in the future and that these states have interests (especially economic) to protect as a matter of a normative imperative the wellbeing of their citizens.

Let me begin by referring to wealthy Western countries as attractors in a world of instability. The dynamic elements of other systems around the world constantly tend to move in the direction of these attractors, and once reached, remain and stabilize in these attractors in preference to other conditions in the surrounding environment. This idea is just an aspect of the Theory of Self-organization, which also indirectly explains 
rural-to-urban migration within states. According to the United Nations Human Settlement Programme (UN-HABITAT) 2014 report, half the world lives in cities, and this will rise to $60 \%$ by 2030 . But the rural to urban migration rate within developing nations is twice the global speed. In certain developing countries, the speed is more than twice: many times over. The report cites that the population of cities in Nigeria and other developing nations will increase from 1.9 billion in 2000 to 3.9 billion in 2030. This is a very conservative estimate. In an estimate done by the Lagos state government, the city of Lagos in Nigeria jumped from 1.4 million people in 1970 to 21 million in 2018. John Vidal (2018, pars 1 and 2) writes,

The 1960 street map of Lagos, Nigeria, shows a small western-style coastal city surrounded by a few semi-rural African villages. Paved roads quickly turn to dirt and fields to forest. There are few buildings over six floors high and not many cars. No one foresaw what happened next. In just two generations, Lagos grew 100-fold, from under 200,000 people to nearly 20 million. Today one of the world's 10 largest cities, it sprawls across nearly $1,000 \mathrm{sq} \mathrm{km}$. Vastly wealthy in parts, it is largely chaotic and impoverished. Most residents live in informal settlements or slums. The great majority are not connected to piped water or a sanitation system. The city's streets are choked with traffic, its air is full of fumes, and its main dump covers 40 hectares and receives 10,000 metric tons of waste a day.

Rural to urban migration accounts for up to $75 \%$ of the population increase (Adelekan 2009). There is flooding and loss of wetland (Adelekan 2009). According to the BBC, "Every week tens of thousands of people arrive in Lagos, heading to neighbourhoods where friends and relatives have come before - many end up in the slums" (BBC 2018, par 13). There is a consensus belief that the rural to urban migration rates in developing countries like this is terrifying. The urban population in Ghana is growing by roughly $5 \%$ annually, due mainly to rural-urban migration (DeGraft 1974, 471). In fact, Vidal suggests that the changes Lagos has seen in the last 60 years may be nothing to what might take place in the next 60 . If Nigeria's population continues to grow and people move to cities at the same rate as now, Lagos could become the world's largest metropolis, home to 85 or 100 million people. By 2100 , it is projected to be home to more people than California or Britain today and to stretch hundreds of miles - with enormous environmental effects (Vidal 2018, par 3).

Niamey, the barely known capital of Niger - a west African country with the highest birth rate in the world - could explode from a city of fewer than one million people today to be the world's eighth-largest city, with 46 million people, in 2100. Sleepy Blantyre in southern Malawi could mushroom to the size of New York City today. In 35 years, more than 100 cities will each have populations larger than 5.5 million people. By 2100, say the authors, the world's population centers will have shifted to Asia and Africa, with only 14 of the 101 largest cities in Europe or the Americas.

What happens to those cities over the next 30 years will determine the global environment and the quality of life of the world's projected 11 billion people (Vidal 
2018, pars 4-6). Similarly, Kinshasa (capital of the Democratic Republic of Congo) had just 20,000 people in 1920 . By 1940 it was home to about 450,000 people. Today it has possibly 12 million and is predicted to be Africa's second largest city with 75 million people inside 50 years. By western standards, it is a dysfunctional, sprawling megalopolis, ringed by vast shantytowns of informal settlements, their infrastructure nonexistent or collapsing (Vidal 2018, 19).

The impact of this phenomenon on the environment is equally terrifying. In their research about the migration and growing population of Bangalore, India, Ramachandra et al. (Ramachandra et al., cited in Vidal 2018, pars 12 and 13) write,

... temperature in the city has increased by $2-2.5 \mathrm{C}$ over the past three decades, while the water table has declined in places from 28 metres down to 300 metres deep; there has been an $88 \%$ loss of vegetation and a $79 \%$ loss in wetlands, and frequent flooding even during normal rainfall... Air pollution is at dangerous levels, the water is polluted, there is nowhere for the waste to go, and the lakes have been killed.

Why this rate of rural-urban migration? There is, of course, the extreme poverty of the rural areas in developing countries to blame (Internet Geography 2018), but the factor relevant to our analysis is that there are no closed borders in rural to urban migration within sovereign states. It is this sort of freedom of movement that open border theorists advocate across countries. An open border world, although still a world of borders, would allow just about anyone (except terrorists and serious security threats) to migrate to more advanced economies where incomes are high, and living conditions trump what is available in developing economies. When we consider that over $90 \%$ of the world's rural-to-urban migration is occurring in developing countries (Rakotonirina and Cheng 2015, 335), it takes little convincing to conclude that this flow will re-direct to richer global destinations in a world of open borders.

There is debate about whether migration undermines or benefits sending countries (see Giovanni et al. 2015). But this debate is restricted to medical brain drain. The debate is also premised on closed borders, which are somewhat selectively "open" (in many cases not substantially open) to people with health skills. What open borders would do is to open borders, not just to medical skills, but to just about anyone (medical and other skills). We are here not just talking about people with health skills, but the entire lower middle class (as well as much of the general middle class) of developing countries. By the 2000s, closed borders were adding an average of 10 to 30 percent in migrant population to countries such as Australia, Canada, and New Zealand, and witnessing a migrant loss of 30 percent to developing countries such as Mexico, El Salvador, and Jamaica (Giovanni et al. 2015). These figures should pale in comparison to the last 18 years (2010 onwards). And inequality has deepened to inclement degrees since. What if borders are opened according to the specification of the open border proponents? What if, for instance, visa requirements for entering the USA are canceled in all her embassies and replaced with only a routine background check against names 
on the US terrorism list? Therefore, we should expect from open borders a mass movement akin to nothing we have been working or researching with. All the research that has been done regarding the advantages and disadvantages of brain drain and gain are, therefore, not even remotely applicable to an open borders scenario.

The emigration rate of some under-developed countries in the current closedborder world should provide some insight about reflecting on open borders. According to Kieran Oberman, "In Granada, Haiti, and Jamaica, the skilled emigration rate is above 80 percent. In Africa, Cape Verde has a rate of 68 percent; Mauritius, 56 percent; Sierra Leone 52 percent; and Ghana, 47 percent" $(2013,428)$. The consequences of this exodus of skilled labor could be disastrous. Oberman $(2013,429)$ writes,

Consider the case of the Zambian health care system. For a population of almost 12 million people, Zambia has only 646 doctors and 6,096 nurses. Between 1998 and 2003, 461 Zambian nurses were recruited to the United Kingdom. Around half of the 50-60 doctors who graduate from the country's only medical school each year emigrate soon after. Brain drain saps Zambia's power to confront its horrendous levels of malnutrition, disease, and ill health. Fully 1.1 million Zambians have AIDS/ HIV. Life expectancy is just 40 years.

Researching on the current closed-border situation, Giovanni et al. (2015), for instance, find that immigration is not clearly beneficial and sometimes negative for migrant-receiving countries in the short term because "the general equilibrium effect of increased variety is only of limited importance in the short run" (Giovanni et al. 2015, 169). The effect of immigration is clearly beneficial in the long term because of "the general equilibrium response of domestic variety" (Giovanni et al. 2015, 169). Indeed, "Natives in the countries with the largest stocks of immigrants relative to population such as Australia, New Zealand, and Canada, have 5-10\% higher welfare under the current levels of migration compared to the no-migration counterfactual" (Giovanni et al. 2015, 169). Giovanni et al. then tell us that the effect of emigration on countries of migrant origin “depends on a trade-off" (Giovanni et al. 2015, 169). To begin, "source countries would ceteris paribus be better off without emigration because a larger labor force implies greater variety in production and consumption. On the other hand, absent emigration there would be no remittances" (Giovanni et al. 2015, 169).

The question then is the trade-off between the loss of labor force and the gain of economic remittances from the skilled labor that was lost to the more advanced nations. For some countries, the remittances may justify the labor skill loss, but for some others, the labor skill loss is more. Giovanni et al. $(2015,169)$ write,

For countries such as El Salvador or the Philippines, where remittances account for more than ten percent of GDP, the latter effect dominates, and the average native stayer is about $10 \%$ better off under the current levels of migration... However, the remittance effect is not always larger than the general equilibrium variety effect. Some important emigration 
countries, such as Mexico, Trinidad, and Tobago, and Turkey, would actually be $1-5 \%$ better off in the no-migration counterfactual.

The authors argue that the short and long term effects of emigration in source countries are the same "because for these countries welfare changes are driven primarily by the loss of remittances, which is the first-order effect in both the short and the long-run" (Giovanni et al. 2015, 169). The authors then conclude, "the distributional impact of migration is also limited in the sending countries, as the impact of emigration on the skill premium is small compared to the remittance effect" (Giovanni et al. 2015, 169).

There are a number of issues that arise from Giovanni et al.'s research. First, they based their research on calculating the variety of production and consumption occasioned by the loss or gain of skilled workers of variety. The findings are thus about how variegated the economy gets when it gains (or loses) skilled labor of variety. The first is that we could not know how the scenario turns out in a much more liberal world of open borders. Second, remittances are perishable monies, but skilled labor is more permanent. And third, the authors did not convincingly analyze the long-term effects of losing skilled labor in source countries. What we have as available is that these countries have generally not gotten better off through the last century (although I would not argue that losing skilled labor is the only or major cause). The point is that we have little to suppose that developing countries would be better off losing skilled labor in the magnitude possible in an open border world.

We could in fact, compare remittance arguments to the idea of trickle-down economics, a now-discredited theory that advocates reducing taxes for the rich or other policies favoring them to produce more so that the effects of their progress would trickle down to the poor in the long term. It is a supply-focus kind of economics. This theory now flies in the face of the increasing disequilibrium we are seeing today, in which the rich are getting exponentially richer than the rest of the human population (currently the richest 80 persons own as much as the rest of humanity), and world poverty has remained or deepened. It beats the imagination that developing nations could lose whatever could possibly be lost through open borders and gain in the long term. There may be no way of broadly calculating this potential loss, just as there was no way of broadly predicting the yawning inequality playing out today in an open-borders scenario. It is true that leaders of countries losing migrants are not doing enough to build their economies (which is in fact the reason for the loss of skilled workers), and it may be true that the benefits and losses of losing skilled labor to more advanced economies are not very clear especially for the long term, but I do not see how opening borders could help, from the perspective of the countries losing skilled migrants.

Oberman cites some authors who have argued that immigration should be restricted because of the brain drain it causes for source countries. He cites four conditions that could justify restricting the immigration of skilled workers to rich countries, and he argues that some of the conditions are not successful. The conditions are as follows: 
1. The skilled worker owes assistance to her poor compatriots.

2. The skilled worker has a duty to stay in her state of origin to provide the assistance she owes her poor compatriots.

3. It is permissible to enforce a skilled worker's duty to stay and assist her poor compatriots using immigration restrictions.

4. The rich state has the legitimacy to impose counter-brain-drain immigration restrictions.

Oberman $(2013,440)$ argues that in relation to condition 1 , there are two types of assistance skilled workers could offer their poor compatriots: "obligation of repayment" and "duty of assistance." He argues that skilled workers acquired their skills at the expense of their poor countries and owe debt either in money or labor. He agrees that the skilled worker owes her compatriots and country a repayment and also assistance. But he disagrees that a skilled worker needs to stay in order to repay what she owes her society for her training. Oberman argues that the skilled worker can repay from abroad. He advises poor states to tax their emigrants, as the USA does since this could generate huge revenues that were not possible if the skilled workers stayed home. Besides, the advanced countries could help them collect these taxes for them (2013, 440). One of Oberman's supporting arguments is that other skilled workers at home will replace the skilled workers. My problem with this supporting argument is that it derives its force from a closed border scenario. First, the rate of emigration in Haiti, Jamaica, and Granada (over 80\%) is a warning of a potential rate in an open border scenario. It does not seem that such an emigration rate allows an efficient replacement of skilled labor, no matter how much revenue the country is making from taxing skilled emigrant labor. So we should be prepared to consider the scenario of a financially buoyant government without adequate skilled labor. But I doubt that such a government will be financially buoyant, and this leads me to the second and more serious problem, which is that the skilled worker population represents the middle class: the foundation of democracy. Without such a class, no government is under check, and governments would generally deteriorate in behavior. With such a high rate of brain drain, therefore, it seems to me that the governments of migrant countries will lack the democratic criticisms of a robust middle class and will generally mismanage or embezzle the revenues accruable from taxing skilled emigrant labor. We need to bear in mind that migrants are not just people who are dissatisfied with the living conditions in their home country but invariably also dissatisfied with how their home country is run. Therefore, opening borders raises moral questions concerning its potential capacity to increase political impunity and corruption (which in turn have the potential to emasculate the economic wellbeing of migrant source countries). This takes me to my third point.

Beyond economic consequences, we need to discuss more importantly the political consequences of brain drain, especially when the political has consequences on the economic. Since those who are likely to migrate are skilled workers, opening borders would strictly undermine the middle-class population in developing countries. Unfortunately, the middle class is usually the main driver of liberal democratic values 
in any society. The very rich and poor are unable to advance liberalism for different reasons, the former because it does not help them consolidate political power, and the latter because they are too dispossessed and disoriented to do so. It does not also help to consider that most migrants migrate in search of better democratic environments, in addition to better economic benefits. Open border increases the ability of lovers of democracy (or at least those who are tired of living under non-democratic conditions) to leave their home states, undermining further the democratic capital of these states (at the macro and long term level) and presenting a concern that these countries could get progressively more authoritarian and totalitarian. Unfortunately, authoritarianism and totalitarianism are effective tools for safeguarding and protecting corruption and deepening world poverty and inequality.

Let me come back to the economic discussion. Oberman argues that the obligation of helping one's compatriots is only a reason to stay back in a poor country if the cost (or condition) of living is reasonable. Oberman cites the extremely poor conditions of working in Zambia to show that the condition may not be reasonable for many poor countries $(2013,441)$. But it seems to me that if Zambia did not already suffer a brain drain, a more robust middle class could have forced a more responsible democratic growth that, ultimately, improves working conditions. Oberman even cites the low staff to patient ratio in health care as a reason for health care professionals to leave (Ibid). But this shows that Oberman is thinking only about the welfare of the professional and not about the professional's clients. If it is a brain drain that caused a low staff-to-patient ratio, I fail to see how further brain drain could ameliorate it.

I will not address Oberman's conditions 3 and 4 since they concern the questions of whether advanced economies have the legitimacy to restrict immigration. This has little to do with my problem, which is to raise moral questions about the economic and especially political effects of an open border scenario on countries that migrants are leaving. I am not just dealing with the legitimacy and justification of advanced countries to restrict the immigration of skilled migrants, but the legitimacy and justification of migrant home countries in restricting the emigration of their skilled citizens. So I am more concerned with conditions 1 and 2, which deal with reasons for justifying the movement, irrespective of whether the restricting is to be done by the sending or receiving country.

If my open border fears for weaker economies merit any attention, then it introduces a fresh moral perspective into the open border debate, a perspective not yet articulated in connecting open borders and an open-border brain drain. If (as the cosmopolitans argue) it is undemocratic to deny a migrant from a less developed country entry because she has not satisfied (seemingly arbitrary) requirements set by the host country, it seems equally undemocratic to open the borders and ultimately kill the growth potential of the home country of migrants simply because they need to be given a chance of better life. It seems a superior moral argument to focus on what is causing migrants to leave their countries than to cause emptying of much of the talented contents of those countries into more advanced economies through open borders. As a general parameter for debating, it seems to me that favoring the 
individual migrant is a short-term humanitarian gesture but favoring the growth of her home country is the long-term one. Imagine, for instance, that we continued with our preoccupation with the former and continued to ignore the latter.

An important aspect of the dimension I am introducing into this debate concerns the relative importance given to the individual and the community in deciding how many persons can migrate or whether we should open borders. In citing a list of the individual's rights, including the individual's right to go wherever she wants to make a better living, the cosmopolitans are clearly neo-liberals who place the welfare of the individual above the welfare of the community. Those who oppose borders are, on the other hand, concerned about the destabilizing effects of open borders on the communities and cultures of the countries receiving migrants. I am now saying we should think about the welfare of the communities migrants are leaving. What is, therefore, clear is that only the neo-liberals favor open borders. Communitarians in the countries receiving migrants seek to protect their communities, and I seek to protect the communities of countries losing migrants. However, the two categories of communitarians seek to protect quite different things. Whilst the communitarians on the richer side are seeking to protect the cultural identities of their communities, I seek to protect the economic and political health of migrant-sending countries.

An objection might arise that open border proponents have themselves argued that they are aware their position is utopian in the current scheme of things. According to this objection, what cosmopolitans envisage is "the original position," Rawls' veil of ignorance, a hypothetical situation of asking what kind of world we would have chosen were we given the opportunity before the beginning of time. And in this original position, we are all ignorant of the world inequality and on which side of the inequality we will be. Since none of us (including me) would have chosen closed borders, this potential objection would point out that I miss the original point of open borders proponents. To this objection, I will also point out that no one in the veil of ignorance would choose open borders along with the huge inequality in the world today. We would all originally choose open borders together with equality: we would choose open borders because the world is constituted of roughly equal economic hemispheres, and the majority of the global movement is not driven by the desire to escape crushing poverty. We would all prefer a world in which we all move around for the reasons that those in the advanced countries move around within their countries or across fellow advanced countries. It appears to me that not even Rawls would originally wish for a deep global inequality, and then desire that everyone is permitted to move to centers of attraction, whose strength of attraction is determined by the severity of inequality, with all the consequences that could attend to areas whose political self-determination is ultimately being undermined by the movement. This all means that it is, in the first place, technically irrelevant to appeal to Rawls' original position because of our concerns about today's vast inequalities. And it seems patently unjust (to use a blunt term) for cosmopolitans to prescribe open borders as a solution to the global economic disparities we have today.

This leads to my last point. Scholars on the cosmopolitan and statist sides of the open border debate have hinted at the role that a world government (or at least a 
supranational institution) could play in an open borders scenario (Wellman and Cole 2011, 125-132; Carens 2013, 270). I will add that open borders is only viable in the emergence of a supranational or global government that, as a preamble to opening borders, addresses gross global inequality in a manner that effectively moderates the hell-fleeing motivations underlying current mass migration movements, if it is especially established that a combination of open borders and such widespread motivations could ultimately kill the self-determination of migrant source countries at the macro level. In light of these considerations, I recommend further research, especially by researchers in migrant countries, on the possible effects of a projected open border scenario on the economies of their countries, especially in the absence of the world government remedy. I am not convinced that current research takes such a context seriously since such research has been mostly by scholars in advanced countries seeking to justify the brain drain in one way or another.

\section{CONCLUSION}

The moral debate on immigration (known as the open border debate) has until now been centered on the interests and rights of the individual migrant versus the interests and rights of host states and original citizens and communities of host states. The interests of the countries losing skilled migrants are missing from the moral debate. There are studies of brain drain, but such debates have been limited to medical brain drain, and they are premised on closed borders. What this article has done is to ask what open borders would mean for not just medical brain drain but the potential migration of much of the lower middle class of weaker economies. It hints that open borders in the context of the current severe global inequalities imply not just unprecedented losses of skill but also losses to the democratic viability of migrant source countries. It questions the moral propriety of prioritizing the interests of the individual migrant if it is, via open borders, at the expense of the migrant's home country. However, it calls for further research by scholars of migrant countries on the more comprehensive effects of brain drain in their countries, in both economic and political terms.

\section{REFERENCES}

\section{Adelekan, Ibudun O. 2009. Vulnerability of poor urban coastal communities to} climate change in Lagos. Available at http://siteresources.worldbank.org/INTURBANDEVELOPMENT/Resources/33 6387- 1256566800920/adelekan.pdf. Accessed: September 18, 2018.

BBC. 2018. The city that won't stop growing: How can Lagos cope with its spiraling population? Available at https://www.bbc.co.uk/news/resources/idt-sh/lagos. Accessed: September 18, 2018.

Carens, Joseph. 2013. The ethics of immigration. Oxford and New York: Oxford 


\section{University Press.}

Cisneros, Natalie. 2013. Alien sexuality: Race, maternity, and citizenship. Hypatia 28(2): 290-306.

De-Graft, Johnson. 1974. Population growth and rural-urban migration, with special reference to Ghana. International Labour Review 109 (5-6): 471-485.

Fine, Sarah. 2016. Is there an unqualified right to leave? In Migration in Political Theory: The Ethics of Movement and Membership. Edited by Sarah Fine and Lea Ypi Oxford: Oxford University Press.

Giovanni, Julian di, Andrei A. Levchenko, and Francesc Ortega. 2015. A global view of cross-border migration. Journal of the European Economic Association 13(1): 168-202.

Higgins, Peter. 2013. Immigration justice. Edinburgh: Edinburgh University Press.

Internet Geography. 2018. What causes population growth in Lagos? Available at https://www.internetgeography.net/topics/what-causes-population-growth-inlagos/. Accessed: September 18, 2018.

Jaggar, Alison. 2009. Transnational cycles of gendered vulnerability. Philosophical Topics 37(2): 33-52.

Kittay, Eva Feder. 2009. The global heart transplant and caring across national boundaries. The Southern Journal of Philosophy 46: 138-165.

Macedo, Stephen. 2007. The moral dilemma of US Immigration Policy: Open borders versus social justice. In Debating Immigration. Edited by C. M. Swain. Cambridge: Cambridge University Press.

Mendoza, Jose Jorge. 2015. Doing away with Juan Crow: Two standards for just immigration reform. APA Newsletter on Hispanic/Latino Issues in Philosophy 15(2): 14- 20.

Miller, David. 1995. On nationality. New York: Oxford University Press.

Narayan, Uma. 1995. Male order brides: Immigrant women, domestic violence and immigration law. Hypatia 10(1): 104-119.

Oberman, Kieran. 2013. Can brain drain justify immigration restrictions? Ethics 123: $427-455$.

Parekh, Serena. 2012. Does ordinary justice make extraordinary injustice possible? Gender, structural injustice and refugee camps. Journal of Global Ethics 8(2-3): 269- 281.

Rakotonirina, Jeremy Desire and Jinhua Cheng. 2015. Research on the impacts of rural-to-urban migration on demographic characteristics regarding economic development in Madagascar. American Journal of Industrial and Business Management 5: 335-350.

Reed-Sandoval, Amy. 2015. Deportations as theaters of inequality. Public Affairs Quarterly 20(2): 201-216.

Reed-Sandoval, Amy. 2016. The new open borders debate. In The Ethics and Politics of Immigration. Edited by Alex Sager. London and New York: Rowman and Littlefield.

Sanchez, Carlos Alberto. 2011. On documents and subjectivity: The formation and deformation of the immigrant identity. Radical Philosophy Review 14(2): 197-205. 
Silva, Grant J. 2015. On the militarization of borders and the judicial right to exclude. Public Affairs Quarterly 29(2): 217-234.

Vidal, John. 2018. The 100 million city: Is $21^{\text {st }}$ century urbanization out of control? The

Guardian.

Available

at https://www.theguardian.com/cities/2018/mar/19/urban- explosion-kinshasa-elalto-growth-mexico-city-bangalore-lagos. Accessed: September 18, 2018.

UN-HABITAT. 2014. State of African cities 2014, re-imagining sustainable urban transitions. Available at https://unhabitat.org/books/state-of-african-cities-2014re- imagining-sustainable-urban-transitions/ Accessed: September 21, 2018.

Walzer, Michael. 1983. Spheres of justice. New York: Basic Books.

Wellman, Christopher Heath and Phillip Cole. 2011. Debating the ethics of immigration: Is there a right to exclude? Oxford and New York: Oxford University Press.

Wilcox, Shelley. 2007. Immigrant admissions and global relations of harm. Journal of Social Philosophy 38: 274-291. 